\title{
Criteria adopted for school menu planning within the framework of the Brazilian School Feeding Program
}

\author{
Critérios adotados para a elaboração de \\ cardápios no Programa Nacional \\ de Alimentação Escolar
}

\author{
Vitória Uliana BIANCHINI1 ${ }^{1}$ 0000-0001-6355-7867

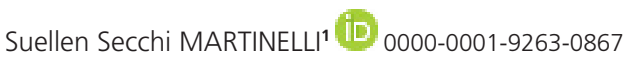 \\ Panmela SOARES ${ }^{1}$ (D) 0000-0002-2449-6886 \\ Rafaela Karen FABRI ${ }^{1}$ (D) 0000-0001-5282-9951 \\ Suzi Barletto CAVALLI ${ }^{1}$ (D) 0000-0002-2835-9424
}

\section{A B S T R A C T}

\section{Objective}

This study aimed to investigate the main criteria used by nutritionists to plan school menus within the framework of the Brazilian National School Feeding Program.

\section{Methods}

Nutritionists from 21 municipalities in Southern Brazil were interviewed. Municipalities had between 20,000 and 70,000 inhabitants and were located in different mesoregions. Data were collected using an open-ended questionnaire and subjected to content analysis using $\mathrm{NVivo}^{\circledR}$ software.

\footnotetext{
1 Universidade Federal de Santa Catarina, Departamento de Nutrição, Programa de Pós-Graduação em Nutrição. R. Delfino Conti, s/n., Campus Universitário, Trindade, 88040-900, Florianópolis, SC, Brasil. Correspondence to: SS MARTINELLI. E-mail: <suellen.smartinelli@gmail.com>.

Support: This study was supported by the Conselho Nacional de Desenvolvimento Científico e Tecnológico (CNPq, Brazilian National Council for Scientific and Technological Development) (Process n. 483184/2012-8).

Article based on the master's dissertation of VU BIANCHINI, entitled "Critérios de sustentabilidade para o planejamento de cardápios escolares no âmbito do Programa Nacional de Alimentação Escolar". Universidade Federal de Santa Catarina, Santa Catarina, 2017.
}

\section{How to cite this article}

Bianchini VU, Martinelli SS, Soares P, Fabri RK, Cavalli SB. Criteria adopted for school menu planning within the framework of the Brazilian School Feeding Program. Rev Nutr. 2020;33:e190197. https://doi.org/10.1590/1678-9865202033e190197 


\section{Results}

Sixteen criteria were identified, grouped into four categories: (1) food habits, culture, and acceptance; (2) nutritional characteristics; (3) food availability; and (4) management and execution. Brazilian National School Feeding Program regulations were recurrently cited within all identified categories, which demonstrates the influence of the program on nutritionists' activities.

\section{Conclusion}

Brazilian National School Feeding Program regulatory guidelines for the development of school menus seem to influence the decision making of nutritionists. However, food purchase from family farms and calculation of meal nutritional value seem to be incipient criteria.

Keywords: Menu planning. Nutrition Programs. School feeding.

\section{RE S U M O}

\section{Objetivo}

Explorar os principais critérios utilizados na elaboração de cardápios escolares na perspectiva de nutricionistas que participam do Programa Nacional de Alimentação Escolar.

\section{Métodos}

Foram entrevistadas nutricionistas responsáveis pela alimentação escolar de 21 municípios de diferentes mesorregiões da região Sul do Brasil que possuíam entre 20 e 70 mil habitantes. Utilizando um questionário aberto, as nutricionistas foram interrogadas sobre os critérios utilizados na elaboração dos cardápios. O conteúdo dos questionários foi analisado com auxilio do software NVivo®.

\section{Resultados}

Dezesseis critérios foram identificados e agrupados em quatro categorias: (1) hábitos, cultura alimentar eaceitação; (2) características nutricionais; (3) disponibilidade de alimentos; (4) gestão e execução. A regulamentação do Programa foi um critério recorrente em todas as categorias, demonstrando sua influência nas atividades das nutricionistas.

\section{Conclusão}

Os critérios estabelecidos pela legislação do Programa Nacional de Alimentação Escolar para a elaboração de cardápios parecem influenciar a tomada de decisões das nutricionistas. O cálculo nutricional dos cardápios e a compra de alimentos produzidos pela agricultura familiar, no entanto, parecem ser critérios ainda incipientes.

Palavras-chave: Planejamento de cardápio. Programas de nutrição. Alimentação escolar.

\section{NTRODUCTION}

Public school feeding policies are associated with improved learning and cognitive performance, reduced school absenteeism, and healthier dietary habits among schoolchildren [1,2]. For these reasons, several countries have government recommendations on school meal preparation, food acquisition, and menu planning [2,3]. For instance, Germany, Denmark, Sweden, Bolivia, Chile, Paraguay, South Africa, and the United States have guidelines addressing the nutritional quality of meals served in the school environment [3-5]. A common recommendation is to preferentially purchase locally grown produce, seen in guidelines from Germany, Brazil, Bolivia, Chile, the United States, Paraguay, and Switzerland [4].

The Programa Nacional de Alimentação Escolar (PNAE, Brazilian National School Feeding Program) resolution has been revised several times since its creation to improve the quality of foods served in schools. Its latest revision states that school menus "should respect nutritional references, eating habits, and local food culture and should stimulate local sustainability, seasonality, agricultural 
diversification, and healthy and adequate food choices" [6,7]. The document defines different guiding criteria, which encompass food purchase practices (such as the mandatory purchase of family farm products), compliance with nutritional parameters based on type of meal and target group, quantity of fruits offered, and restrictions on the acquisition of foods rich in sugar or sodium [6].

Although PNAE provides regulatory guidelines, school nutritionists and executive managers have some level of autonomy in the development of school menus [8]. Furthermore, school menu planning must take into account several aspects that are not defined by legislation, such as school infrastructure, equipment, utensils, human resources, food preparation techniques, and combinations of ingredients, colors, and shapes [9].

Some studies have assessed the importance of school nutritionists for the implementation and management of PNAE, whereas others have analyzed the nutritional quality of school menus in Brazil [10-16]. However, to the best of our knowledge, no research has been conducted on the role of nutritionists in school menu planning. Given the need to improve compliance with PNAE guidelines $[6,7]$ and the importance of school meals for the formation of healthy eating habits and the provision of quality food to students $[1,17,18]$, particularly in situations of social vulnerability [19], this study aimed to investigate the main criteria used for the development of school menus from the perspective of nutritionists in charge of the school feeding program in different municipalities in Southern Brazil.

\section{METHOD S}

This cross-sectional study adopted a qualitative and quantitative approach based on open-ended interviews with nutritionists responsible for school meals in 21 municipalities in Southern Brazil. To ensure the inclusion of nutritionists from municipalities with different socioeconomic, geographic, and cultural characteristics, we used probabilistic cluster sampling by mesoregions. Municipalities with 20,000 to 70,000 inhabitants were randomly selected. Municipal education departments were contacted by telephone and invited to participate in the study. All municipalities that accepted participation and hired public school nutritionists were included in the study. Of the 23 mesoregions in Southern Brazil, 2 in Paraná were excluded from the study because they declined participation or did not fulfill the inclusion criteria.

Interviews were conducted by trained nutritionist researchers between March and November 2015, during field visits to the interviewee's workplace. Prior to the interviews, participants were informed of the study objectives and assured of their anonymity. All participants signed an informed consent form before participation. This study was approved by the Research Ethics Committee of the Federal University of Santa Catarina (Protocol n. 1,002,956).

The municipalities included in the study had an average of 22 school units and 78,000 enrolled students. One interview was carried out per municipality, always with the nutritionist responsible for planning the school menus. It should be noted that, in eight municipalities, more than one nutritionist was in charge of this activity. In these cases, two or three professionals were interviewed together. Results are expressed by municipality.

An interview guide was prepared by the research team in collaboration with nutrition experts and tested in a pilot study. The first section of questions gathered information on the general characteristics of the municipality and the interviewee. The second section addressed the development of school menus and was designed in such a way so as to divide the remaining time of the interview 
into two moments. In the first moment, interviewees provided responses without influence from the interviewer, which allowed to identify and quantify their menu planning criteria. In the second moment, questions were aimed at encouraging a deeper discussion of the investigated topics and measures adopted in relation to each item (Chart 1). The average interview time was 14 min (range, $7 \mathrm{~min}$ to $37 \mathrm{~min}$ ). Interviews were audio-taped and transcribed for analysis.

A qualitative and quantitative analysis of interview data was performed to explore the main criteria used by nutritionists to create school menus. First, criteria were identified by content analysis using NVivo ${ }^{\circledR}$ software version 11 [20,21]. Transcripts were repeatedly read for familiarization, text fragments with similar meanings were coded, and categories were constructed by combining codes that shared similar themes. Subsequently, codes were analyzed quantitatively to identify the criteria most frequently cited by school nutritionists. Medians were calculated, and data are presented by code citation frequency within each category. For improved data reliability, coding and categorization were performed by two different researchers, and discrepancies were resolved by consensus.

\section{R E S U L T S}

Descriptive statistics of the number of enrolled students and school nutritionists by municipality are presented in Table 1. Municipalities had on average 34,132 inhabitants, with a range of 20,841 to 69,968 inhabitants. There were on average 22 school units per municipality, with a range of 9 to 35 school units. The 31 interviewees were female and had an average professional experience of 8 years in the municipality (range, 0.5 years to 30 years).

Content analysis of interviews identified four categories of criteria that guide nutritionists in planning school menus within the PNAE framework (Chart 2). The central theme of this study, PNAE regulations, was related to all categories; that is, all mentioned criteria were, to a greater or lesser extent, encompassed by PNAE guidelines.

Chart 1. General topics discussed in open-ended interviews with school nutritionists.

\begin{tabular}{l}
\hline \multicolumn{1}{c}{ General interview guide } \\
\hline Municipality and interviewee characteristics \\
\hline State \\
Municipality \\
Number of inhabitants \\
Number of school units \\
Number of enrolled students \\
Number of school nutritionists \\
Nutritionists' experience in the school environment \\
Gender \\
\hline School menu planning \\
\hline 1. What are the three main criteria that you use to plan school menus? \\
2. Which of the following criteria influence school menu planning? \\
Food nutritional composition \\
Seasonality \\
Availability of locally grown products \\
Students' eating habits \\
Cost \\
School kitchen infrastructure \\
Ease/complexity of preparation \\
Number of staff members \\
Food acceptance by students \\
Brazilian National School Feeding Program guidelines \\
Delivery schedule
\end{tabular}


Table 1. Distribution of evaluated municipalities by number of students and nutritionists participating in the Programa Nacional de Alimentação Escolar, Brazil.

\begin{tabular}{lcc}
\hline Parameter & N of municipalities & $\%$ \\
\hline Number of students attended by PNAE & 1 & 4.8 \\
2.000 to 2.500 & 16 & 76.2 \\
2.500 to 5.000 & 4 & 19.0 \\
$>5.000$ & & 61.9 \\
Number of school nutritionists & 13 & 28.6 \\
1 & 6 & 9.5 \\
2 & 2 & \\
3 & & \\
\hline
\end{tabular}

Note: PNAE: Programa Nacional de Alimentação Escolar.

Chart 2. Central theme, categories, and codes used for content analysis of interviews with nutritionists.

\begin{tabular}{|c|c|c|c|c|}
\hline \multirow{2}{*}{$\begin{array}{l}\text { Central theme } \\
\text { Categories }\end{array}$} & \multicolumn{4}{|c|}{ Brazilian National School Feeding Program Regulations } \\
\hline & $\begin{array}{c}\text { Food habits, culture, and } \\
\text { acceptance }\end{array}$ & Nutritional characteristics & Food availability & Management and execution \\
\hline \multirow{5}{*}{ Codes } & Food habits and culture & $\begin{array}{l}\text { Nutritional requirements } \\
\text { and food nutritional value }\end{array}$ & Seasonality & Costs and financial resources \\
\hline & Acceptance and preferences & $\begin{array}{l}\text { Qualitative nutritional } \\
\text { characteristics }\end{array}$ & $\begin{array}{l}\text { Availability of family } \\
\text { farm products }\end{array}$ & School infrastructure \\
\hline & $\begin{array}{l}\text { Habit formation/food and } \\
\text { nutrition education }\end{array}$ & & $\begin{array}{l}\text { Availability of other } \\
\text { suppliers }\end{array}$ & Difficulty of meal preparation \\
\hline & $\begin{array}{l}\text { Influence and acceptance of } \\
\text { parents and teachers }\end{array}$ & & & Supplier delivery schedule \\
\hline & & & & $\begin{array}{l}\text { Number of students attended } \\
\text { Amount of time students } \\
\text { spend at school } \\
\text { Staff availability }\end{array}$ \\
\hline
\end{tabular}

The median number of guiding criteria by municipality was 3 (range, 2 to 6). The most frequently cited criteria were within the categories "Food habits, culture, and acceptance" and "Nutritional characteristics" as shown in Figure 1.

Programa Nacional de Alimentação Escolar regulations and recommendations permeated all identified categories. In general, nutritionists applied the legislation as their major decision support tool for planning school menus. Nevertheless, some recommendations were considered difficult to implement, such as nutritional value calculation, acceptability testing, and food purchase from family farms. As stated by one of the interviewees: "We work in compliance with the legislation to create the school menus. And even if we are unable to comply with something, we [...] provide a justification, whether it is financial, whether it is not grown in our region, the reason why" (Interviewee C).

Participants regarded food habits and culture as important criteria for the development of school menus and underscored the need to consider the cultural specificities of different schools within the same municipality: "Each location is different here, each daycare center, each school. That's why everything is different [the menus]" (Interviewee F).

With respect to the need to account for students' food preferences and acceptance, the interviewees suggested the importance of involving and communicating with other school professionals, such as teachers and cooks: "Because of our work routine, we are unable to do it [acceptability testing]. We gather information from school cooks, teachers..." (Interviewee J). 


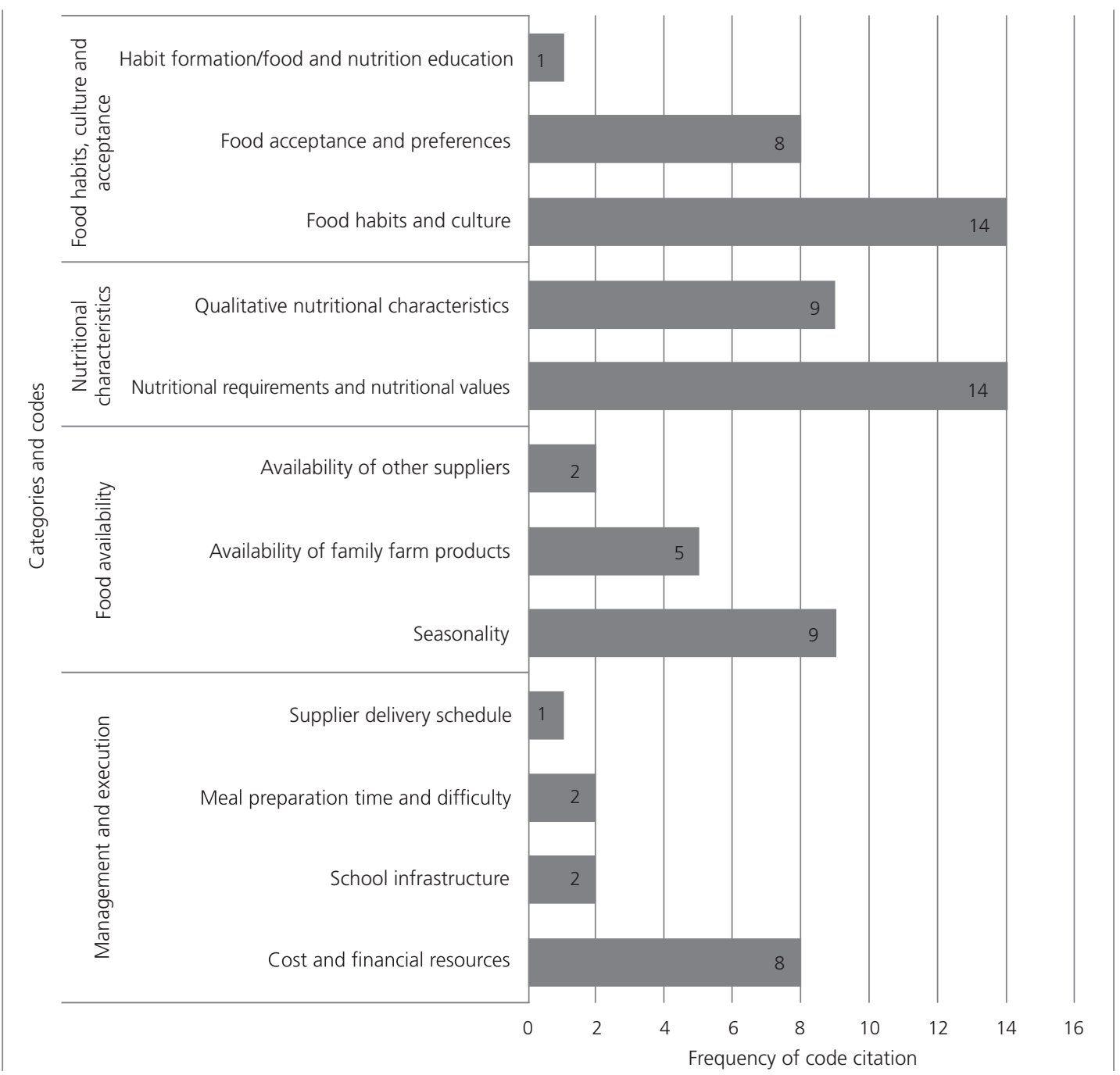

Figure 1. Graphical representation of the criteria adopted by nutritionists to plan school menus, stratified according to the categories and codes used in content analysis of interviews.

Parents and teachers were mentioned as important influences on food acceptance and the development of healthy eating habits: "If the teacher does not side with you about a food, you can put it as many times as you want on the menu that the children won't eat it. The teacher is always the child's reference" (Interviewee L).

Calculation of meal nutritional value was one of the most frequently cited criteria for menu planning. However, some nutritionists considered this item difficult to comply with, maily because of lack of time, insufficient staff resources or difficulties in achieving requirements for some micronutrients. To circumvent the difficulty of determining the nutritional value of meals, school nutritionists sought to comply with other PNAE recommendations on menu composition (referred to in this article as qualitative nutritional aspects). For instance, nutritionists avoided the use of processed foods in an attempt to not exceed the maximum limits of simple sugars, fats, and sodium imposed by legislation. This strategy was also associated with the prohibition of the purchase of beverages with low nutritional value and the restriction of food items that were recommended against by the regulation: "I make sure that we have healthy foods, low in fat, almost free of sodium. And we prefer natural products, nothing processed" (Interviewee L). 
Providing the minimum servings of fruits and vegetables and limiting the inclusion of sugary foods were considered easily applicable criteria: "That is, when it comes to fruits and vegetables, the main requirements, we are able to meet. Not including so many sweet preparations, not buying products that you shouldn't, all that we follow" (Interviewee J).

Regarding food availability, some concerns were raised about family farm produce. Nutritionists often maintained wholesale markets as collateral suppliers in the event of problems with family farms. The major issues of supply problems were related to adverse weather conditions, low product variety, and unregulated animal products: "I have to have both [types of suppliers] because there are some essential products, like onions, for example. If it is not available from family farms, I request it by procurement" (Interviewee B).

To guarantee a continuous food supply, some interviewees adopted a participatory development strategy through the exchange of information with farmers: "We try to develop the school menu based on what they [farmers] have. They send us a list of products that they produce and we work with that list" (Interviewee M).

School nutritionists attributed great importance to seasonality. According to some respondents, seasonality can be positive in economic terms (prices are lower) and in terms of food acceptance and reduced waste generation: "Accounting for seasonality, the food is tastier, has higher quality, and costs less. It is easily accessible" (Interviewee $\mathrm{H}$ ).

Interviewees differed in their views on the influence of food prices on school menu planning. This contrast is evident between the following statements: "We don't stop buying because of cost. We first plan the menu and then calculate the costs. If the cost exceeds our resources, the municipality covers it" (Interviewee R). "We have limited resources regardless of PNAE; thus, if on the contrary it is possible to spend nothing, this is preferable" (Interviewee L).

Nutritionists cited the schools' infrastructure (physical space, equipment, and utensils) as a limiting factor in the development of school menus, and, in some cases, as a food safety risk factor. Sometimes, the choice for simple food preparations was made to guarantee compliance with food safety and hygiene standards by the kitchen staff: "If we complicate their lives, it is a shot in the foot. So, one day we elaborate more, right? And on the next, the food is simpler. Because we know that they have to clean and sanitize, so they will not be able to do it properly [if the preparation is too complex]" (Interviewee C).

The number of students served and the time students spent at school were also reported as factors influencing the choice of food preparations. In general, the greater the number of students, the greater the difficulty in preparing more complex recipes. The presence of full-time students necessitated a greater variety of food preparations.

Some workforce characteristics imposed restrictions on school menu planning, such as low employee qualification and insufficient staff. Another common complaint was that the kitchen staff were resistant to the idea of preparing dishes that demand extra effort. Foods purchased from family farms had a major drawback in this respect, as they generally required a greater number of pre-preparation steps. Interviewees reported that a solution to these difficulties was to start preparing the ingredients days before serving the meals. Another solution was to purchase minimally processed foods.

School menus were influenced by food delivery schedules. In most municipalities, delivery dates were defined according to the supplier's availability. 


\section{DISCUSSION}

This study explored the criteria used by PNAE school nutritionists from different municipalities in Southern Brazil for the development of school menus. Nutritionists mainly took into account the food habits, preferences, and acceptance of students. However, nutritionists did not view school menus as a tool for Food and Nutrition Education (FNE). Meal nutritional quality was pointed out as the main criterion; however, many nutritionists expressed their difficulty in calculating the nutritional value of meals. Although food acquisition from family farms is part of PNAE regulations, the interviewees reported challenges in buying food from these farming systems, particularly with regard to food availability. Less frequently, the cost was referred to as a limiting factor, which was directly associated with the low financial contribution from municipalities. PNAE regulations emerged as a central topic, as they permeated all categories identified from the interviews.

Eating habits and student acceptance were important factors guiding menu planning by school nutritionists. The criteria are related, as students tend to accept foods that are compatible with local eating habits $[22,23]$. Previous studies have underscored the importance of conducting acceptability tests which, in fact, are mandatory according to PNAE regulations $[6,24,25]$. However, interviewees reported that it is difficult to carry out such tests and, in some cases, it is not possible to comply with the regulation, as also observed in other studies $[10,11]$. A study associated acceptability testing with the time of nutritionists' participation in PNAE. The results showed that testing is performed more frequently when the nutritionist has participated in the program for 2 to 5 years and less frequently in the case of more than 5 years of participation [12]. This association may explain the interviewees' difficulty in carrying out this activity, as nutritionists had a mean of 8 years of experience in school menu planning.

Despite being one of the main goals of school feeding, the formation of healthy eating habits was cited by only one nutritionist as a guiding criterion. The non-adherence of students to PNAE menus is influenced not only by sociodemographic variables, routine and access to competing foods but also by the lack of FNE $[24,26,27]$. Thus, FNE is an important strategy to increase adherence to and acceptance of school meals and healthy eating habits $[24,26,27]$. The inclusion of FNE in the school curriculum was associated with cultivation of vegetable gardens, greater use of foods from family farms, and promotion of cooking classes in the school environment [28]. The legislation defines the provision of healthy foods and the use of food as a pedagogical tool as FNE actions [6]. Viewed in this light, the planning of school menus is, in itself, an FNE action [29]. However, the perception of menu planning by nutritionists as a purely administrative responsibility is recurrent including by other key education agents and considered a barrier to FNE [30,31].

Although meal nutritional quality was pointed out as an important criterion in menu planning, many nutritionists expressed difficulty in calculating the nutritional value of meals. Such results agree with those of previous studies showing that lack of time, precarious and unsafe working conditions, and insufficient staff numbers are the main barriers to the calculation of the nutritional value of meals [10-12]. This activity is required by PNAE regulation, and non-compliance can have a negative impact on the quality of school meals [6]. In order to assist nutritionists in planning meals, the Fundo Nacional de Desenvolvimento da Educação (FNDE, National Education Development Fund) provides tools to support nutritional quality assessment, such as Plan PNAE for quantitative analysis, and the Índice de Qualidade da Coordenação de Segurança Alimentar Nutricional (IQ COSAN, Quality Index of the Food and Nutrition Security Coordination) for qualitative analysis [32,33]. Both tools were made available to the interviewees after the completion of the study and will likely contribute to reducing the difficulties identified. 
The availability of food from family farms was highlighted as one of the major criteria in 5 of the 21 municipalities analyzed. Studies have shown that irregular supply of food, inadequate hygiene and sanitary conditions, and lack of farmers or coordination between sectors are the major factors affecting the purchase of food from family farms [34-38]. On the other hand, over the years, municipalities have been able to overcome such barriers and increase the acquisition of food from family farms $[34,36,39,40]$. For advances in this regard, it is essential that actors from the different sectors involved - from those associated with policy-making to those related to the execution, monitoring, and evaluation of actions - communicate and work together toward a similar goal $[35,36,41]$. An example of such collaboration is the planning of school menus in accordance with food availability, as identified in the current study [34,42]. This dialogue helps to create healthier menus that include a variety of vegetables and fruits and promote sustainability by rescuing culinary traditions and fostering the local economy [43-45].

The Programa Nacional de Alimentação Escolar recommends prioritizing the use of organic foods but this guideline was not mentioned by the interviewees [6]. The high cost and low availability of such foods probably led nutritionists to not consider organic foods during school menu planning $[37,46,47]$. The legislation recommends but does not establish quantitative parameters for the inclusion of organic foods in school menus. Therefore, the incorporation of more defined criteria on the use of organic food may influence and stimulate their application on a regular basis [48].

Municipal bodies are required by PNAE regulation to complement the financial aid provided by FNDE [6]. Nevertheless, food cost was regarded as a limiting factor in menu planning. Studies showed that municipal investment in PNAE ranges from 49 to $379 \%$ compared with federal resources $[49,50]$. Some municipal bodies, however, do not contribute at all [51]. It is crucial that municipalities contribute financially to ensure food and nutrition security [51]. The provision of high-quality, varied meals can increase the level of satisfaction of students [23]. It is the municipality's responsibility to provide the structure and human resources needed for school feeding [6].

Programa Nacional de Alimentação Escolar regulations and guidelines strongly influenced the criteria adopted by nutritionists for menu planning [23]. The nutritionists interviewed in this study showed a willingness to comply with legal recommendations despite the obstacles encountered. Problems associated with nutritionists' working conditions, including work overload, short working hours, and few personnel, have been widely discussed $[11,37,52,53]$. Lack of support from school managers and resistance from kitchen and pedagogical staff have also been reported as barriers to menu planning [53]. Therefore, improvement of working conditions and knowledge sharing with other professionals are identified as strategies to facilitate the activities of school nutritionists $[37,52]$.

According to FNDE, the school nutritionist is the technician in charge of school feeding [6]. The minimum number of school nutritionists is defined on the basis of data from the Federal Council of Nutritionists $[6,54]$. For instance, a minimum of four professionals are required in municipalities with more than 2,500 students [54]. However, this is not the reality of the municipalities evaluated in the current study, where the number of professionals was below the recommended. The lack of professionals may explain the difficulty that nutritionists had in carrying out the activities assigned to them. Thus, it follows that compliance with PNAE regulations can be promoted by ensuring the minimum number of required personnel, which should be supervised by the responsible bodies [52].

In addition, it is important that nutritionists recognize menu planning as their main work tool and as the first stage of the meal production process [55]. The activities of the school nutritionist 
include planning school menus, monitoring food preparation, and evaluating the nutritional quality of meals. Such actions should be carried out on the basis of nutritional references, local food habits and culture, and the local agricultural scenario [54]. Therefore, menu planning demands time, dedication, and commitment to health promotion [9].

We highlight that the opinion of the interviewees may have been influenced by their professional interests. However, a general insight into the main criteria used for planning school menus was made possible by interviewing professionals from different municipalities and mesoregions and with different years of experience. The study was focused on the Southern region of Brazil; therefore, the results are not representative of the whole country.

\section{CONCLUSION}

School nutritionists from Southern Brazil take into account nutritional recommendations, meal acceptance, and local eating habits when planning school menus. PNAE regulations permeated interviewees' statements, suggesting the importance of the program's regulation in promoting healthy and sustainable food systems. However, few nutritionists regard the calculation of meal nutritional values and the purchase of food from family farms, which are pillars of PNAE, as criteria for menu planning. Failure to incorporate these criteria suggests weaknesses in the process of menu planning. Given the importance of school meals for FNE, it is necessary to adopt measures that facilitate the incorporation of the criteria established by PNAE. Hiring the minimum number of nutritionists required per region can reduce difficulties and increase compliance with program directives.

\section{CONTRIBUTORS}

VU BIANCHINI was responsible for data collection, analysis, interpretation, discussion, and writing of the manuscript. SS MARTINELLI, P SOARES, and RK FABRI designed the original study, coordinated data collection and manuscript development, and contributed to data analysis and discussion. SB CAVALLI was responsible for coordinating the investigation, guiding the analyses, and revising the final version of the manuscript. All authors declare that there is no conflict of interest regarding this study.

\section{REFERENCES}

1. Locatelli NT, Canella DS, Bandoni DH. Positive influence of school meals on food consumption in Brazil. Nutrition. 2018;53:140-4. https://doi.org/10.1016/j.nut.2018.02.011

2. Drake L, Woolnough A, Burbano C, Bundy D, (ed.). Global school feeding sourcebook: lessons from 14 countries. London: Imperial College Press; 2016. https://doi.org/10.1142/p1070

3. Joint Research Centre. School food policy country factsheets: 2015. Brussels: European Commission; 2015 [cited Sept. 30 2019]. Available from: http://ec.europa.eu/jrc/en/publication/school-food-policy-country-factsheets

4. World Food Programme. Smart school meals: nutrition-sensitive national programmes in latin america and the caribbean: a review of 16 countries. Rome: WFP; 2017 [cited Sept. 30 2019]. Available from: http://docs. wfp.org/api/documents/WFP-0000019946/download/

5. Soares P, Martínez-Milán MA, Comino I, Caballero P, Davó-Blanes MC. Valoración del documento de consenso sobre alimentación en centros educativos para evaluar menús escolares. Gac Sanit. 2019;34(3):225-9. https:// doi.org/10.1016/j.gaceta.2019.08.008

6. Ministério da Educação (Brasil). Fundo Nacional de Desenvolvimento da Educação. Resolução $n^{\circ}$ 26, de 17 de junho de 2013. Brasília: Ministério; 2013. 
7. Ministério da Educação (Brasil). Fundo Nacional de Desenvolvimento da Educação. Lei n 11.947, de 16 de junho de 2009. Brasília: Ministério; 2009.

8. Teo CRPA, Monteiro CA. Marco legal do Programa Nacional de Alimentação Escolar: uma releitura para alinhar propósitos e prática na aquisição de alimentos. Rev Nutr. 2012;25(5):657-68. https://doi.org/10.1590/ S1415-52732012000500010

9. Proença RPC, Sousa AA, Veiros MB, Hering B. Qualidade nutricional e sensorial na produção de refeições. Florianópolis: Editora da UFSC; 2008.

10. Corrêa RS, Rockett FC, Rocha PB, Silva VL, Oliveira VR. Atuação do nutricionista no Programa Nacional de Alimentação Escolar na região sul do Brasil. Ciênc Saúde Coletiva. 2017;22(2):563-74. https://doi. org/10.1590/1413-81232017222.09622016

11. Souza AA, Bezerra OMPA, Bonomo E, Silva CAM. Atuação de nutricionistas responsáveis técnicos pela alimentação escolar de municípios de Minas Gerais e Espírito Santo. Ciênc Saúde Coletiva. 2017;22(2):593606. https://doi.org/10.1590/1413-81232017222.12272016

12. Mello AL, Vidal Júnior PO, Sampaio LR, Santos LAS, Freitas MCS, Fontes GAV. Perfil do nutricionista do programa nacional de alimentação escolar na região nordeste do Brasil. Rev Nutr. 2012;25(1):119-32. https://doi.org/10.1590/S1415-52732012000100011

13. Soares DSB, Barbosa RMS, Henriques P, Dias PC, Ferreira DM. Análisis de la calidad de los menús del Programa de Alimentación Escolar Nacional en una ciudad de Río de Janeiro: Brasil. Rev Chil Nutr. 2015;42(3):235-40. https://doi.org/10.4067/S0717-75182015000300002

14. Longo-Silva G, Toloni M, Rodrigues S, Rocha A, Taddei JAAC. Qualitative evaluation of the menu and plate waste in public day care centers in São Paulo city, Brazil. Rev Nutr. 2013;26(2):135-44. https://doi. org/10.1590/S1415-52732013000200002

15. Vidal GM, Veiros MB, Sousa AA. School menus in Santa Catarina: evaluation with respect to the National School Food Program regulations. Rev Nutr. 2015;28(3):277-87. https://doi.org/10.1590/141552732015000300005

16. Leão PV, Dias RM, Frazão AGF, Dias IA, Silva IRP, Corrêa NAF, et al. Nutritional analysis of the School Feeding Program menus offered in a municipality of Pará. Mundo Saúde. 2018;42(1):18. https://doi. org/10.15343/0104-7809.20184201181198

17. Azeredo CM, Rezende LFM, Canella DS, Claro RM, Peres MFT, Luiz OC, et al. Food environments in schools and in the immediate vicinity are associated with unhealthy food consumption among Brazilian adolescents. Prev Med. 2016;88:73-9. https://doi.org/10.1016/j.ypmed.2016.03.026

18. Meiklejohn S, Ryan L, Palermo C. A systematic review of the impact of multi-strategy nutrition education programs on health and nutrition of adolescents. J Nutr Educ Behav. 2016;48(9):631-46. https://doi. org/10.1016/j.jneb.2016.07.015

19. Horta PM, Carmo AS, Junior EV, Santos LC. Consuming school meals improves Brazilian children's diets according to their social vulnerability risk. Public Health Nutr. 2019;22(14):2714-9. https://doi.org/10.1017/ S1368980019001459

20. Bardin L. Análise de conteúdo. São Paulo: Edições 70; 2016.

21. QSR International. NVivo: version 11. Melbourne: QSR International; 2015 [cited Sept. 30 2019]. Available from: https://www.qsrinternational.com/nvivo-qualitative-data-analysis-software/home

22. Paiva JB, Freitas MCS, Santos LAS. Hábitos alimentares regionais no Programa Nacional de Alimentação Escolar: um estudo qualitativo em um município do sertão da Bahia, Brasil. Rev Nutr. 2012;25(2):191-202. https://doi.org/10.1590/S1415-52732012000200002

23. Gabriel CG, Costa LCF, Calvo MCM, Vasconcelos FAG. Planejamento de cardápios para escolas públicas municipais: reflexão e ilustração desse processo em duas capitais brasileiras. Rev Nutr. 2012;25(3):363-72. https://doi.org/10.1590/S1415-52732012000300006

24. Oliveira MC, Vassimon HS. Programa Nacional de Alimentação Escolar e sua aceitação pelos alunos. Investigação. 2012;12(1):4-10. https://doi.org/10.26843/investigacao.v12i1.614

25. Raphaelli CO, Passos LDF, Couto SF, Helbig E, Madruga SW. Adesão e aceitabilidade de cardápios da alimentação escolar do ensino fundamental de escolas de zona rural. Braz J Food Technol. 2017;20:1-9. https://doi.org/10.1590/1981-6723.11216 
26. Locatelli NT, Canella DS, Bandoni DH. Fatores associados ao consumo da alimentação escolar por adolescentes no Brasil: resultados da PeNSE 2012. Cad Saúde Pública. 2017;33(4). https://doi.org/10.1590/0102$311 \times 00183615$

27. Valentim EA, Almeida CCB, Taconeli CA, Osório MM, Schmidt ST. Fatores associados à adesão à alimentação escolar por adolescentes de escolas públicas estaduais de Colombo, Paraná, Brasil. Cad Saúde Pública. 2017;33(10). https://doi.org/10.1590/0102-311x00061016

28. Ottoni IC, Oliveira BMPM, Bandoni DH. The national school feeding program as a promoter of food and nutrition education actions in Brazilian schools. Mundo Saúde. 2019;43(2):16. https://doi.org/10.15343/01047809.20194302374389

29. Fundo Nacional de Desenvolvimento da Educação. Programa Nacional de Alimentação Escolar. Brasília: FNDE; 2018 [citado em 9 set. 2019]. Disponível em: https://www.fnde.gov.br/programas/pnae/pnae-sobreo-programa/pnae-historico

30. Cervato-Mancuso AM, Moraes da Silva G, Pava Cárdenas A. Grupo focal con nutricionistas que actúan en la alimentación escolar: el menú como elemento pedagógico. Rev Chil Nutr. 2013;40(3):250-5. https://doi. org/10.4067/S0717-75182013000300006

31. Assao TY, Westphal MF, Bógus CM, Cervato-Mancuso AM. Alimentação do escolar: percepção de quem prepara e oferece as refeições na escola. Segur Aliment Nutr. 2012;19(1):22-32. https://doi.org/10.20396/ san.v19i1.8634666

32. Fundo Nacional de Desenvolvimento da Educação. PlanPNAE: ferramenta de planejamento de cardápio. Brasília: Fundo Nacional de Desenvolvimento da Educação; 2018 [citado em 18 dez. 2019]. Disponível em: http://www.fnde.gov.br/index.php/programas/pnae/pnae-area-gestores/ferramentas-de-apoio-aonutricionista/item/12820-plan-pnae-ferramenta-de-planejamento-de-card\%C3\%A1 pio

33. Fundo Nacional de Desenvolvimento da Educação. Índice de qualidade da coordenação de segurança alimentar nutricional: IQ COSAN. Brasília: FNDE; 2018 [citado em 18 dez. 2019]. Disponível em: http:// www.fnde.gov.br/index.php/programas/pnae/pnae-area-gestores/ferramentas-de-apoio-ao-nutricionista/ item/12142-iq-cosan

34. Soares P, Martinelli SS, Melgarejo L, Davó-Blanes MC, Cavalli SB. Potencialidades e dificuldades para o abastecimento da alimentação escolar mediante a aquisição de alimentos da agricultura familiar em um município brasileiro. Ciênc Saúde Coletiva. 2015;20(6):1891-900. https://doi.org/10.1590/141381232015206.16972014

35. Assis TRP, França AGM, Coelho AM. Agricultura familiar e alimentação escolar: desafios para o acesso aos mercados institucionais em três municípios mineiros. Rev Econ Sociol Rural. 2019;57:577-93. https://doi. org/10.1590/1806-9479.2019.187826

36. Elias LP, Belik W, Cunha MP, Guilhoto JJM. Impactos socioeconômicos do Programa Nacional de Alimentação Escolar na agricultura familiar de Santa Catarina. Rev Econ Sociol Rural. 2019;57:215-33. https://doi. org/10.1590/1806-9479.2019.171266/

37. Ferreira DM, Barbosa RMS, Finizola NC, Soares DdSB, Henriques P, Pereira S, et al. Perception of the operating agents about the Brazilian National School Feeding Program. Rev Saúde Pública. 2019;53(34). https://doi. org/10.11606/s1518-8787.2019053000597

38. Rockett FC, Corrêa RS, Pires GC, Machado LS, Hoerlle FS, Souza CPMD, et al. Family farming and school meals in Rio Grande do Sul, Brazil. Ciênc Rural. 2019;49(2). https://doi.org/10.1590/0103-8478cr20180561

39. Machado PMO, Schmitz BAS, González-Chica DA, Corso ACT, Vasconcelos FAG, Gabriel CG. Compra de alimentos da agricultura familiar pelo Programa Nacional de Alimentação Escolar (PNAE): estudo transversal com o universo de municípios brasileiros. Ciênc Saúde Coletiva. 2018;23(12):4153-64. https://doi.org/10.15 90/1413-812320182311.28012016

40. Araujo LRS, Brito ANM, Rodrigues MTP, Mascarenhas MDM, Moreira-Araujo RSR. Alimentação escolar e agricultura familiar: análise de recursos empregados na compra de alimentos. Cad Saúde Pública. 2019;35(11). https://doi.org/10.1590/0102-311X00004819

41. Schwartzman F, Mora CAR, Bogus CM, Villar BS. Antecedentes e elementos da vinculação do programa de alimentação escolar do Brasil com a agricultura familiar. Cad Saúde Pública. 2017;33(12). https://doi. org/10.1590/0102-311x00099816 
42. Sousa AA, Silva APF, Azevedo E, Ramos MO. Cardápios e sustentabilidade: ensaio sobre as diretrizes do Programa Nacional de Alimentação Escolar. Rev Nutr. 2015;28(2):217-29. https://doi.org/10.1590/1415-52 732015000200010

43. Soares P, Davo-Blanes MC, Martinelli SS, Melgarejo L, Cavalli SB. The effect of new purchase criteria on food procurement for the Brazilian school feeding program. Appetite. 2017;108:288-94. https://doi.org/10. 1016/j.appet.2016.10.016

44. Soares P. Using local family farm products for school feeding programmes: effect on school menus. Brit Food J. 2017;119(6):1289-300. https://doi.org/10.1108/BFJ-08-2016-0377

45. Fabri RK. Regional foods in Brazilian school meals. Brit Food J. 2015;117(6):1706-19. https://doi.org/10.1108/ BFJ-07-2014-0275

46. Santos F, Fernandes PF, Rockett FC, Oliveira ABA. Avaliação da inserção de alimentos orgânicos provenientes da agricultura familiar na alimentação escolar, em municípios dos territórios rurais do Rio Grande do Sul, Brasil. Ciênc Saúde Coletiva. 2014;19(5):1429-36. https://doi.org/10.1590/1413-81232014195.14982013

47. Castellani ALA, Trentini T, Nishida W, Rossi CE, Costa LCF, Vasconcelos FAG. Purchase of family farm and organic foods by the Brazilian School Food Program in Santa Catarina state, Brazil. Rev Nutr. 2017;30(5):651-62. https:// doi.org/10.1590/1678-98652017000500010

48. Silverio GA, Sousa AA. Organic foods from family farms in the National School Food Program: perspectives of social actors from Santa Catarina, Brazil. Rev Nutr. 2014;27(3):289-300. https://doi.org/10.1590/1415-527 32014000300003

49. Gabriel CG, Goulart G, Calvo MCM. Gestão municipal do Programa Nacional de Alimentação Escolar nas capitais da região Sul do Brasil. Rev Nutr. 2015;28:667-80. https://doi.org/10.1590/1415-52732015000600009

50. Gabriel CG, Calvo MCM, Vasconcelos FAG, Lacerda JT, Freitas SFT, Schmitz BAS. Avaliação da gestão municipal do Programa Nacional de Alimentação Escolar nos maiores municípios de Santa Catarina, Brasil. Cad Saúde Pública. 2014;30(9):2017-23. https://doi.org/10.1590/0102-311XER00112813

51. Machado PMO, Machado MS, Schmitz BAS, Corsa ACT, González-Chica DA, Vasconcelos FAG. Caracterização do Programa Nacional de Alimentação Escolar no Estado de Santa Catarina. Rev Nutr. 2013;26(6):715-25. https://doi.org/10.1590/S1415-52732013000600010

52. Chaves LG, Santana TCM, Gabriel CG, Vasconcelos FAG. Reflexões sobre a atuação do nutricionista no Programa Nacional de Alimentação Escolar no Brasil. Ciênc Saúde Coletiva. 2013;18(4):917-26. https://doi. org/10.1590/S1413-81232013000400003

53. Scarparo ALS, Oliveira VR, Bittencourt JMV, Ruiz ENF, Fernandes PF, Zys JZ, et al. Formação para nutricionistas que atuam no Programa Nacional de Alimentação Escolar: uma avaliação da efetividade. Ciênc Saúde Coletiva. 2013;18(4):1001-8. https://doi.org/10.1590/S1413-81232013000400013

54. Conselho Federal de Nutricionistas (Brasil). Resolução n 465, de 23 de agosto de 2010. Brasília: Diário Oficial da União; 2010.

55. Conselho Federal de Nutricionistas (Brasil). Resolução n 600, de 25 de fevereiro de 2018. Brasília: Diário Oficial da União; 2018. 